\title{
Transmissão de Begomovírus de Plantas daninhas para TOMATEIROS PELA MOSCA-BRANCA ${ }^{1}$
}

\author{
Begomovirus Transmission from Weeds to Tomato by the Whitefly \\ SILVA, A.K.F. ${ }^{2}$, SANTOS, C.D.G. ${ }^{3}$ e NASCIMENTO, A.K.Q. ${ }^{4}$
}

\begin{abstract}
RESUMO - Dentre numerosas enfermidades do tomateiro (Lycopersicon esculentum), destacamse as viroses causadas por begomovirus, os quais são transmitidos pelo vetor Bemisia tabaci biótipo B. Na Chapada da Ibiapaba-CE, os begomovírus têm sido encontrados em várias áreas onde o tomateiro é cultivado, causando sérios danos à produção. Este trabalho teve por objetivos investigar a transmissão de begomovirus a partir de tomateiros infectados para plantas daninhas e verificar seu retorno das plantas daninhas para o tomateiro. Mudas sadias de tomateiro 'Santa Clara' e das plantas daninhas bredo-de-espinho (Amaranthus spinosus), caruru-de-mancha (Amaranthus viridis), mentrasto (Ageratum conyzoides) e picãopreto (Bidens pilosa) foram submetidas à inoculação por dois métodos: com o inseto vetor e por enxertia. Após 15 dias, realizou-se a extração do DNA de amostras foliares dos tomateiros e das espécies daninhas inoculadas. A PCR realizada com oligonucleotídeos degenerados e específicos para begomovirus revelou que na transmissão com o vetor as quatro espécies de plantas daninhas foram infectadas com o begomovirus do tomateiro, enquanto que, por enxertia, apenas o picão-preto foi infectado. O retorno do vírus das plantas daninhas para o tomateiro foi também observado nos dois casos. Percentuais de 70, 50, 20 e 12,5\% de transmissão para os tomateiros ocorreram quando o vetor adquiriu o vírus em mentrasto, bredo-de-espinho, picão-preto e caruru-de-mancha, respectivamente. Na enxertia, a transmissão viral para os tomateiros ocorreu apenas quando se empregaram seções de bredode-espinho e de picão-preto infectados. As espécies daninhas investigadas demonstraram ser hospedeiras alternativas do begomovirus de tomate da região e, em condiçõs de campo e na presença do vetor, podem constituir importantes fontes do begomovirus para a hortaliça.
\end{abstract}

Palavras-chave: Ageratum conyzoides, Amaranthus spinosus, Amaranthus viridis, Bidens pilosa, Lycopersicon esculentum, PCR.

\begin{abstract}
The viruses caused by begomovirus are considered the most important virus diseases affecting tomato plants (Lycopersicon esculentum). They are transmitted by the whitefly, Bemisia tabaci biotype B, and natural infections of those viruses have been reported in weeds, which can constitute important sources of the pathogen for the tomato. In Chapada da Ibiapaba-CE, the begomovirus has been found in numerous areas where tomatoes are cultivated causing serious damage to the production. The aim of this study was to investigate the transmission of begomovirus from infected tomatoes to weeds and from infected weeds to tomatoes. Healthy weed seedlings commonly found in tomato crops, such as Amaranthus spinosus, Amaranthus viridis, Ageratum conyzoides and Bidens pilosa, as well as healthy tomato seedlings were inoculated with the viruses by using the vector or grafting. After 15 days of inoculation, leaves of the weed and tomato plants were collected for DNA extraction. Using specific oligonucleotides for begomovirus in a PCR reaction, the presence of begomovirus could be detected in all four weed species tested when tomato was used as a source of inoculum and whiteflies were used as vector. By grafting, only B. pilosa showed to be infected by begomovirus in the PCR reaction. When the four weed species infected with begomovirus were used as inoculum for the tomato seedlings, the transmission was
\end{abstract}

1 Recebido para publicação em 30.10.2009 e na forma revisada em 3.9.2010.

Parte da dissertação do primeiro autor.

2 M.Sc., Universidade Federal do Ceará - UFC, <kelly.firmino@gmail.com>; ${ }^{3}$ Professora Associada, UFC, <carmelo@ufc.br>; ${ }^{4}$ Estudante de Doutorado em Agronomia, Departamento de Fitotecnia, Centro de Ciências Agrárias, UFC, Avenida Mister Hull, 2977, Campus do Pici, 60356-000 Fortaleza-CE, <alynekellly@yahoo.com.br>.

Planta Daninha, Viçosa-MG, v. 28, n. 3, p. 507-514, 2010 
also detected by PCR. When the vector acquired the virus in $\boldsymbol{A}$. conyzoides, $\boldsymbol{A}$. spinosus, B. pilosa and $\boldsymbol{A}$. viridis, the percentage of transmission to the tomato plants was $70,50,20$ and $12.5 \%$, respectively. The viral transmission through grafting from infected weeds to tomatoes only occurred when infected $\boldsymbol{A}$. spinosus or B. pilosa were used as grafts. The investigated weeds demonstrated to be alternative hosts of the tomato begomovirus, and, under natural conditions and in the presence of the vector, they can be important begomovirus sources for the tomato plants.

Keywords: Ageratum conyzoides, Amaranthus spinosus, Amaranthus viridis, Bidens pilosa, Lycopersicon esculentum, PCR

\section{INTRODUÇÃO}

O tomateiro (Lycopersicon esculentum) é uma hortaliça de grande aceitação entre diferentes mercados consumidores, o que tornou a tomaticultura uma atividade agrícola de grande importância socioeconômica, amplamente difundida no mundo.

Desde a década de 1990, surtos epidêmicos de viroses causadas por begomovirus passaram a ocorrer em todas as regiões produtoras de tomate do Brasil, associados à introdução da mosca-branca, Bemisia tabaci biótipo B (Faria et al., 2000; Ribeiro et al., 2002). Esse vetor transmite begomovirus na modalidade persistente-circulativa, com período de acesso de aquisição (PAA) minimo de 15 minutos, tornando-se mais eficiente com o aumento do PAA e / ou do período acesso de inoculação (PAI) (Muniyappa et al., 2000; Santos et al., 2003). Há relatos de sua passagem transestadial e de transmissão à progênie (transovariana), o que torna o vetor importante na disseminação e manutenção do vírus nas lavouras (Ghanim et al., 1998; Santos et al., 2003). Ressalta-se ainda que $B$. tabaci biótipo B coloniza mais de 500 espécies vegetais distribuídas em 84 famílias botânicas, entre as quais são exemplos a Amaranthaceae, Asteraceae, Malvaceae e Solanaceae (Haji et al., 2004).

Tomateiros infectados por begomovírus apresentam sintomas variados de mosaico, geralmente acompanhado de clorose ou amarelecimento, enrolamento, rugosidade e redução do limbo foliar e graus variados de nanismo (Inoue-Nagata et al., 2005; Arnaud et al., 2007). Os begomovírus não são transmitidos por semente ou por contato entre plantas infectadas e sadias. Sua dispersão ou introdução numa lavoura dá-se pela ação da mosca-branca a partir de fontes de vírus de áreas próximas, podendo ser de cultivos antigos, bem como de fontes alternativas no campo (Costa, 1976; Faria et al., 2000). A virose é considerada, atualmente, um fator limitante à produção da hortaliça em diversas regiões no Brasil, em razão da dificuldade de controle, agravada pela constante migração do vetor entre as lavouras (Faria et al., 2000; Lima et al., 2004; Arnaud et al., 2007).

Diversidade genética tem sido observada em espécies de begomovírus associadas ao tomateiro no Nordeste, Sudeste e CentroOeste do Brasil (Ribeiro et al., 2002). O relacionamento filogenético entre as espécies de begomovírus de tomateiro e de plantas daninhas ressalta a importância destas como prováveis hospedeiras naturais e fontes do virus para a cultura, contribuindo, inclusive, com o surgimento de novas espécies do vírus em razão de ocorrência de recombinações no campo (Ambrozevicius et al., 2002).

Cerca de $15 \%$ dos vírus que afetam plantas foram descritos em associação natural com espécies da vegetação espontânea distribuídas nas famílias Asteraceae, Amaranthaceae, Chenopodiaceae, Commelinaceae, Solanaceae, Fabaceae, Malvaceae, entre outras (Chaves et al., 2003). De acordo com Costa (1998), a disseminação natural de vírus de vegetais ocorre com a eficiente participação de vetores, na grande maioria insetos homópteros. Assim, em condições naturais, é possivel que haja a transmissão de vírus entre plantas da vegetação espontânea e plantas cultivadas, visto que a atividade dos insetos vetores em campo, principalmente sob altas populações, é mais intensa, podendo os vírus chegar mais cedo nos novos plantios (Costa, 1976).

Diversas espécies de plantas daninhas presentes em lavouras de tomate têm sido 
relatadas como hospedeiras de begomovirus no Nordeste (Lima et al., 2002; Santos et al., 2003; Assunção et al., 2006), representando ameaça para a cultura.

De acordo com Arnaud et al. (2007), na Chapada da Ibiapaba-CE, os begomovirus são predominantes nas áreas produtoras de tomate, em razão da constante presença da mosca-branca nas lavouras. Além da hortaliça, várias plantas daninhas já foram encontradas naturalmente infectadas por begomovirus naquela região (Santos et al., 2003; Arnaud et al., 2007). Contudo, são ainda escassas as informações sobre a interação begomovírus, tomate, plantas daninhas e vetor. Diante disso, este trabalho teve como objetivo investigar a transmissão de begomovirus proveniente de tomateiros para plantas daninhas, empregando o vetor e a inoculação por enxertia, bem como verificar seu retorno de plantas daninhas para o tomateiro e, com isso, poder esclarecer se estas são de fato fontes potenciais do patógeno em campo.

\section{MATERIAL E MÉTODOS}

\section{Fonte de inóculo}

Amostras foliares de tomateiros, cultivados na região de Ibiapaba- $\mathrm{CE}$, com sintomas sugestivos de infecção por begomovirus foram submetidas à extração de DNA total e a PCR com oligonucleotídeos específicos para begomovirus. Na eletroforese, o tamanho dos fragmentos de DNA amplificados de 0,9 kb, referente ao gene da capa proteica, confirmou a infecção viral. Amostras de uma única planta foram empregadas para manutenção do virus no tomateiro 'Santa Clara' utilizado como fonte de inóculo neste trabalho, o qual passou a ser referido como BCE-01. Os ensaios foram conduzidos em casa de vegetação e no Laboratório de Virologia Vegetal, na Universidade Federal do Ceará.

\section{Teste de transmissão viral de tomateiro para plantas daninhas}

Nos ensaios de transmissão viral com o BCE-01 empregaram-se duas metodologias: inoculação mediante emprego do inseto vetor e enxertia. As plantas daninhas utilizadas nos ensaios foram as seguintes: bredo-de-espinho (Amaranthus spinosus) e caruru-de-mancha (A. viridis), ambos da família Amaranthaceae, mentrasto (Ageratum conyzoides) e picão-preto (Bidens pilosa), da família Asteraceae. O número de plantas empregado variou conforme a germinação das espécies.

\section{Inoculação empregando mosca-branca}

Tomateiro infectado com o BCE-01 foi colocado em gaiola telada com moscas-brancas avirulíferas. Após um período de acesso de aquisição (PAA) de 24 horas pelo vetor, grupos de 4-9 mudas sadias de bredo-de-espinho, caruru-de-mancha, mentrasto e picão-preto foram, alternadamente, colocados na mesma gaiola, onde permaneceram por sete dias em contato com as moscas-brancas viruliferas. Mudas sadias de tomateiro 'Santa Clara' foram também levadas para a gaiola, para controle da transmissão. Após a retirada das plantas da gaiola, realizaram-se pulverizações de tomateiros e de plantas daninhas com inseticidas sistêmico (imidacloprid na dose de $0,3 \mathrm{~g} \mathrm{~L}^{-1}$ ) e de contato (buprofezin na dose de $1,5 \mathrm{~g} \mathrm{~L}^{-1}$ ) recomendados para mosca-branca. Decorridos 15 dias da retirada de cada grupo de plantas da gaiola, procedeu-se à coleta de amostras foliares de todas as plantas daninhas e das mudas de tomateiro para extração de DNA total e posterior PCR, para confirmação da transmissão.

\section{Inoculação por enxertia}

Seções de ramos novos de tomateiros infectados com o BCE-01 foram obtidas por meio de cortes realizados com lâminas novas de bisturi. Essas seções foram enxertadas por garfagem nas plantas daninhas sadias que se encontravam no estádio de quarta folha verdadeira. Realizou-se um enxerto por planta daninha, o qual foi mantido preso ao caule com auxílio de prendedores plásticos. Empregaram-se de 8 a 10 plantas de cada espécie daninha nos ensaios de enxertia. Mudas sadias de tomate foram igualmente inoculadas, para controle da transmissão. Após emissão de ramos novos, decorridos cerca de duas semanas, amostras foliares foram coletadas para extração de DNA total e posterior PCR.

Planta Daninha, Viçosa-MG, v. 28, n. 3, p. 507-514, 2010 


\section{Teste de transmissão viral de plantas daninhas para tomateiro}

\section{Inoculação empregando a mosca-branca}

Ensaios de transmissão do vírus BCE-01 de plantas daninhas para o tomateiro, visando observar o seu retorno para a solanácea, foram também realizados. Para isso, mudas envasadas de plantas daninhas infectadas foram colocadas em gaiolas individuais com moscasbrancas aviruliferas por um PAA de 24 horas. Depois desse tempo, os insetos foram transferidos, por meio de um aspirador manual, para mudas sadias de tomate com duas folhas definitivas (6-12 insetos por planta), para um PAI de outras 24 horas. Pulverização com inseticida sistêmico foi igualmente realizada. Passados 15 dias da inoculação, foram coletadas amostras foliares dos tomateiros, para procedimento de detecção viral por PCR.

\section{Inoculação por enxertia}

Seções de ramos novos de plantas daninhas infectadas com o BCE-01 foram enxertadas por garfagem em mudas sadias de tomateiro 'Santa Clara', quando estas estavam no estádio de quarta folha verdadeira. As seções foram igualmente presas aos tomateiros com os prendedores plásticos. Após emissão de ramos novos de tomateiros, amostras foliares foram coletadas para confirmação da infecção pelo begomovirus.

\section{Detecção por PCR}

Nas etapas de detecção do vírus, em todas as plantas inoculadas por meio de ambos os métodos, foi realizada a extração de DNA total, empregando o protocolo elaborado por Dellaporta et al. (1983), utilizando os pares de primers PAc368 (CP1) (5'CCCGTCGACATG YCTAAGMGKGAKGCCCC-3') e PAv1320 (CP2) (5'CCCCTGCAGAACTTCCAAGTCTGGACG-3'), os quais originam bandas de $0,9 \mathrm{~kb}$ do DNA A, referentes à capa proteica de begomovirus. O programa utilizado na amplificação do genoma viral no termociclador (Mastercycler gradient-Eppendorf) foi: aquecimento inicial de $94^{\circ} \mathrm{C}$ durante 3 min e 29 ciclos compostos de desnaturação $\left(94^{\circ} \mathrm{C} \mathrm{min}^{-1}\right)$, anelamento $\left(53^{\circ} \mathrm{C} \mathrm{min}^{-1}\right)$ e extensão $\left(72{ }^{\circ} \mathrm{C}\right.$ por $\left.2,0 \mathrm{~min}\right)$, seguido de uma extensão final de $72{ }^{\circ} \mathrm{C}$ por $7 \mathrm{~min}$. Após a eletroforese, os fragmentos de DNA amplificados foram visualizados em gel de agarose $1 \%$, corado com brometo de etídio, e observados sob luz ultravioleta em fotodocumentador (Bio-Rad mini-transiluminator ).

\section{RESULTADOS E DISCUSSÃO}

Observou-se que o begomovirus BCE-01 foi transmitido do tomateiro para as quatro espécies de plantas daninhas, em percentual variando de 20 a $37 \%$, incluindo os dois métodos de inoculação (Tabela 1). Observou-se que, em todos os casos, a transmissão foi mais eficiente quando se empregou o vetor. Em condições naturais, Arnaud et al. (2007) encontraram begomovirus nessas espécies em percentuais de 16\% (mentrasto), 20\% (caruru-de-mancha), $25 \%$ (picão-preto) e $65 \%$ (bredo-de-espinho) das amostras coletadas ao acaso em lavouras de tomate na Chapada da Ibiapaba-CE. A presença do virus em cada planta daninha foi confirmada pela visualização de bandas de $0,9 \mathrm{~kb}$ em gel de agarose $1 \%$ (Figura 1 ). Com esses resultados, constatou-se que o begomovirus de tomate pode ser levado pelo inseto vetor para essas plantas invasoras. No gel, a presença de bandas inespecíficas abaixo da banda viral esperada

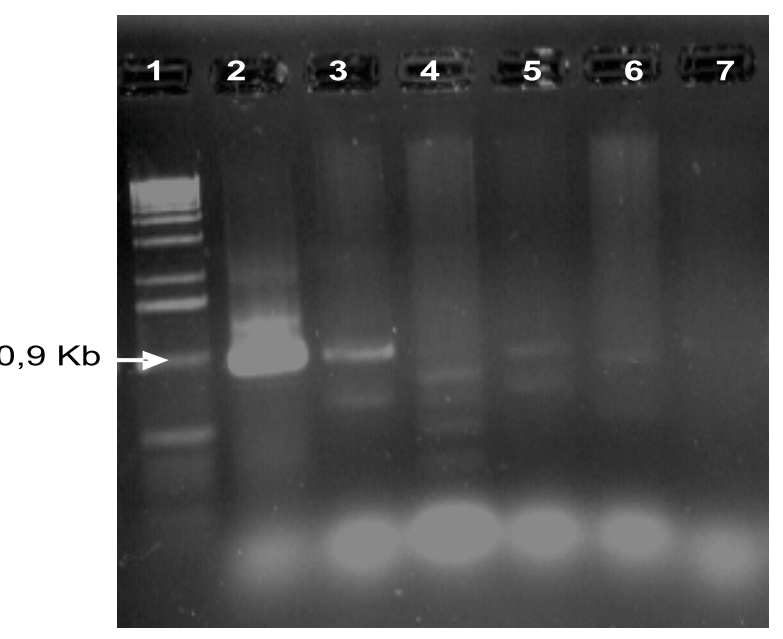

Figura 1 - Análise eletroforética em gel de agarose 1\% de amostras de tomateiro e de plantas daninhas inoculadas com mosca-branca e infectadas com o begomovírus. 1-marcador DNA Ladder $1 \mathrm{~Kb}$; 2-tomate (controle positivo); 3-bredo-de-espinho; 4- mentrasto; 5-carurude-mancha; 6- picãopreto; 7- tomate sadio. 
nas amostras de plantas daninhas pode ser resultante de alguma degeneração de oligonucleotídeos. Bandas degeneradas em gel foram também relatadas por Brioso et al. (1996) para comovirus.

$\mathrm{Na}$ transmissão do begomovírus BCE-01 para plantas daninhas por meio da enxertia com seções de tomateiros, apenas o picão-preto foi infectado com o vírus (Tabela 1). Baixo percentual de sucesso de inoculações por enxertia já foi constatado anteriormente por Arnaud et al. (2007), em tentativas de transmissão de begomovirus isolados de tomateiros infectados para mudas de tomateiro 'Santa Clara'.

As plantas daninhas infectadas com begomovirus nesses ensaios não apresentaram sintomas visíveis de infecção. Contudo, os tomateiros usados como controle positivo, inoculados no mesmo ensaio, exibiram os sintomas de mosaico clorótico, deformação foliar, epinastia e subdesenvolvimento da planta, semelhantes ao do tomateiro usado como fonte viral.

Os resultados dos ensaios visando ao retorno do begomovirus de plantas daninhas para tomateiros sadios, empregando-se a mosca-branca e a enxertia, encontram-se na Tabela 2. Com base nos dados obtidos, observou-se que houve variação de 12 a $70 \%$ na transmissão viral para tomateiros empregando-se a mosca-branca. O menor percentual de transmissão ocorreu quando a fonte de virus

Tabela 1 - Transmissão de begomovírus do tomateiro para plantas daninhas. Fortaleza-CE

\begin{tabular}{|c|c|}
\hline Plantas daninhas inoculadas & $\begin{array}{l}\text { Plantas daninhas } \\
\text { infectadas dentre o total } \\
\text { de plantas testadas }\end{array}$ \\
\hline \multicolumn{2}{|c|}{ Inoculação por mosca-branca } \\
\hline Bredo-de-espinho (Amaranthus spinosus) & $2 / 6(33 \%)^{*}$ \\
\hline Caruru-de-mancha (Amaranthus viridis) & $2 / 9(22 \%)$ \\
\hline Mentrasto (Ageratum conyzoides $)$ & $1 / 4(25 \%)$ \\
\hline Picão-preto (Bidens pilosa) & $3 / 8(37 \%)$ \\
\hline \multicolumn{2}{|c|}{ Inoculação por enxertia } \\
\hline Bredo-de-espinho (Amaranthus spinosus) & $0 / 3(0 \%)$ \\
\hline Caruru-de-mancha (Amaranthus viridis) & $0 / 3(0 \%)$ \\
\hline Mentrasto (Ageratum conyzoides) & $0 / 9(0 \%)$ \\
\hline Picão-preto (Bidens pilosa) & $2 / 10(20 \%)$ \\
\hline
\end{tabular}

foi o caruru-de-mancha (12\%), provavelmente em razão da menor recuperação dos insetos nessa planta daninha (seis por planta) transferidos para as mudas de tomate.

Verificou-se que os valores da transmissão viral foram mais elevados quando ocorreu o retorno do begomovirus para o tomateiro do que deste para as quatro invasoras, levando a supor que a hortaliça seja uma hospedeira mais favorável à infecção viral.

Após 15 dias da inoculação, as plantas de tomateiro infectadas apresentaram sintomas bem definidos da virose - ocasião da coleta das amostras para extração do DNA. Géis ilustrando o resultado da transmissão viral para os tomateiros inoculados podem ser observados nas Figuras 2 e 3. A infecção nos tomateiros foi constatada para todos os casos em que se empregou a mosca-branca, tendo por fonte de begomovirus as quatro plantas daninhas (Figura 2).

$\mathrm{Na}$ inoculação por enxertia, onde seções de ramos de plantas daninhas infectadas foram enxertadas em tomateiros sadios, a transmissão do vírus ocorreu somente quando a fonte foi o picão $(27 \%)$ e o bredo-de-espinho $(40 \%)$ (Figura 3). Umas das possiveis causas do insucesso na transmissão via enxertia com mentrasto e caruru-de-mancha foi o menor número de seções obtido a partir dessas espécies enxertado no tomateiro.

Segundo Arnaud et al. (2007), as quatro espécies daninhas referidas são encontradas com frequência nas lavouras de tomateiro da Chapada da Ibiapaba- $\mathrm{CE}$, sendo comum a presença da mosca-branca em suas folhas, demonstrando a movimentação do inseto entre as espécies de plantas daninhas e o tomateiro. O picão-preto e o bredo-de-espinho já foram relatados como hospedeiros do inseto por Alencar et al. (2006). Conforme Costa (1976), plantas daninhas são usualmente as principais fontes das quais o vetor adquire o vírus e o introduz em novos plantios. Segundo esse autor, o vetor é mais eficiente na transmissão quando adquire o vírus da vegetação espontânea que dentro da própria cultura. Essa afirmativa encontraria explicação na constante presença de plantas daninhas em uma área, as quais, por serem hospedeiras do inseto, são infectadas pelo vírus com mais frequência, 
Tabela 2 - Transmissão de begomovírus das plantas daninhas para tomateiros. Fortaleza-CE

\begin{tabular}{|c|c|}
\hline Tipo de transmissão empregada & $\begin{array}{c}\text { Tomateiros infectados dentre o total de tomateiros } \\
\text { inoculados }\end{array}$ \\
\hline \multicolumn{2}{|c|}{ Inoculação do tomateiro por mosca-branca tendo por fonte viral a planta daninha } \\
\hline Bredo-de-espinho (Amaranthus spinosus) & $5 / 10(50 \%)^{*}$ \\
\hline Caruru-de-mancha (Amaranthus viridis) & $1 / 8(12 \%)$ \\
\hline Mentrasto (Ageratum conyzoides) & $7 / 10(70 \%)$ \\
\hline Picão-preto (Bidens pilosa) & $2 / 10(20 \%)$ \\
\hline \multicolumn{2}{|c|}{ Inoculação do tomateiro por enxertia tendo por fonte viral a planta daninha } \\
\hline Bredo-de-espinho (Amaranthus spinosus) & $2 / 5(40 \%)$ \\
\hline Caruru-de-mancha (Amaranthus viridis) & $0 / 3(0 \%)$ \\
\hline Mentrasto (Ageratum conyzoides) & $0 / 5(0 \%)$ \\
\hline Picão-preto (Bidens pilosa) & $3 / 11(27 \%)$ \\
\hline
\end{tabular}

* Valores entre parênteses representam o percentual de transmissão da virose para as plantas daninhas.

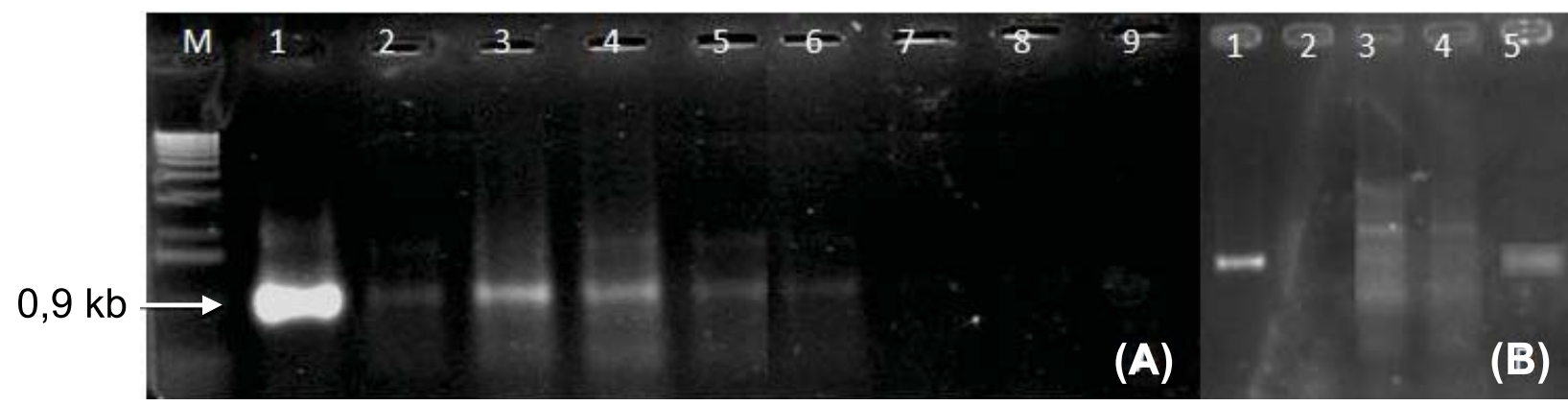

Figura 2 - Análise eletroforética em gel de agarose 1\% de amostras de tomateiro inoculado empregando-se o vetor, tendo por fonte plantas daninhas. (A) 1-marcador DNA Ladder $1 \mathrm{~kb}$; 2- tomateiro 'Santa Clara' (controle positivo); 3-5 - tomateiro (fonte mentrasto); 6-10 tomateiro (fonte bredo-de-espinho. (B) 1- tomateiro (controle positivo); 2- tomateiro sadio; 3-4- tomateiro (fonte picão-preto); 5- tomateiro (caruru-de-mancha).

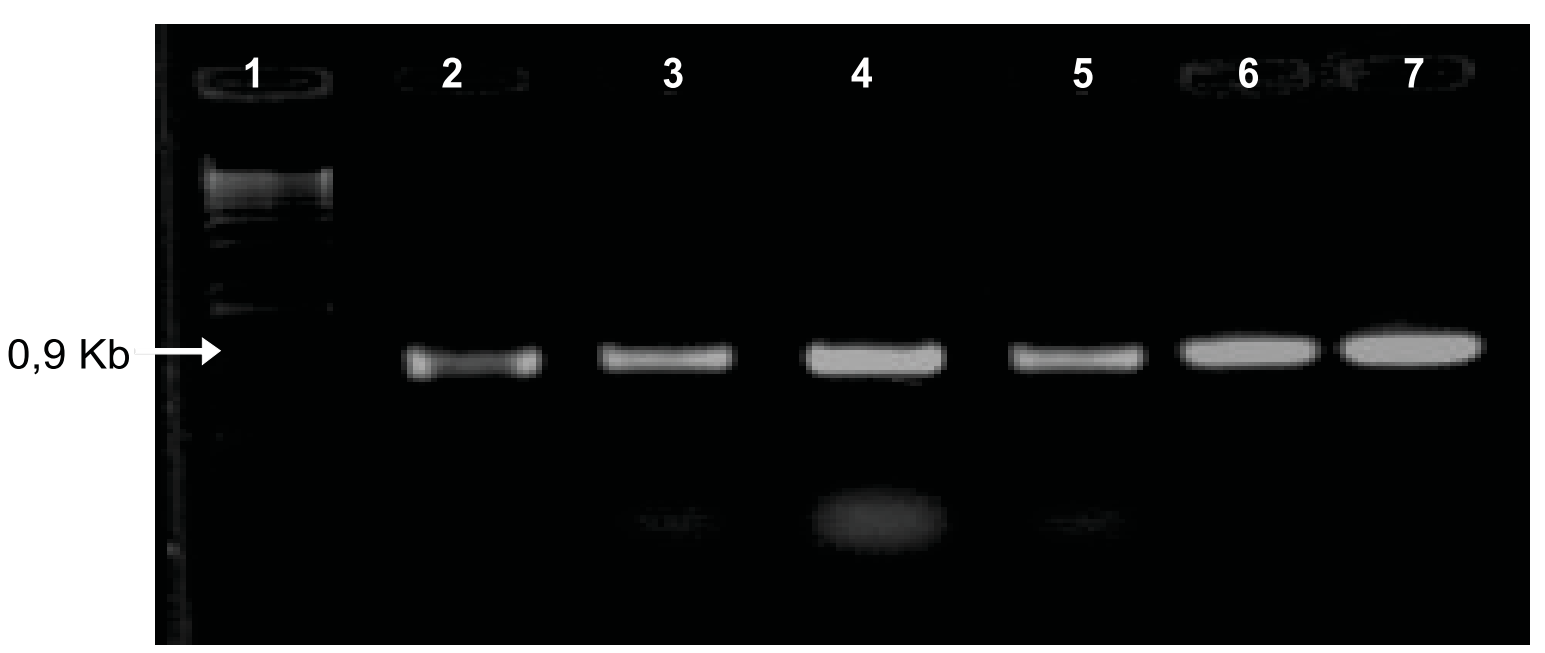

Figura 3 - Análise eletroforética em gel de agarose 1\% de amostras de tomateiros enxertados, tendo por fonte seções de plantas daninhas. 1- marcador DNA Ladder $1 \mathrm{~Kb}$; 2-tomate (controle positivo); 3 -5 tomateiro (fonte picão-preto); 6 e 7-tomateiros (fonte bredo-de-espinho). 
tornando-se importantes fontes do patógeno nas quais o vetor, ao ingerir a seiva, adquire maior carga viral.

Ainda que seja considerada difícil, a prática para a erradicação das espécies daninhas deve ser recomendada visando à redução da incidência da virose no tomateiro, uma vez que as invasoras podem constituir importantes e contínuas fontes do patógeno para a cultura. Esse enfoque é também encontrado em Ambrozevícius et al. (2002), Assunção et al. (2006) e Arnaud et al. (2007), para diferentes áreas cultivadas.

O Lettuce mosaic virus, LMV, é outro exemplo de vírus que tem plantas daninhas como hospedeiras naturais. Chaves et al. (2003) relataram que buva (Erigeron bonariensis) pode atuar como reservatório natural do LMV e que a sua erradicação torna-se prática recomendada para o controle do virus em áreas produtoras de alface (Lactuca sativa). Na cultura do mamão (Carica papaya), apesar do apelo agroecológico da manutenção da vegetação natural, a prática da eliminação das plantas daninhas é recomendada para controle dos afideos que transmitem o Papaya ringspot virus- $\mathrm{P}$, vírus causador de uma das principais doenças da cultura. Nesse caso, as plantas daninhas agem como hospedeiras do inseto vetor (Ronchi et al., 2008).

O begomovirus BCE-01 está sendo caracterizado molecularmente. No Ceará, estudos com diferentes enzimas de restrição aplicadas a produtos de RCA (rolling circle amplification) obtidos de plantas daninhas e de tomateiros naturalmente infectados na região da Ibiapaba$\mathrm{CE}$ têm revelado uma variação de padrões de restrição. Segundo Inoue-Nagata (2009), a análise da clivagem com enzimas de restrição de produtos de RCA permite uma avaliação preliminar da diversidade genética de begomovírus em amostras.

Os resultados dos ensaios demonstraram que as plantas daninhas bredo-de-espinho, caruru-de-mancha, mentrasto e picão-preto são hospedeiras alternativas de begomovirus de tomate e que podem, no campo e na presença do vetor, constituir importantes fontes de begomovirus e/ou de recombinantes para o tomateiro.

\section{LITERATURA CITADA}

ALENCAR, J. A.; KIILL, L. H. P.; ALENCAR, P. C. G. Identificação e descrição de plantas invasoras hospedeiras da mosca-branca Bemisia spp. In: ALENCAR, J. A. (Ed.). Identificação de plantas invasoras e silvestres hospedeiras da mosca-branca no semi-árido do Nordeste brasileiro. Fortaleza: BNB; Embrapa, 2006. p. 37-124. (BNB. Série Ciência e Tecnologia).

AMBROZEVICIUS, L. P. et al. Genetic diversity of begomovíruses infecting tomato and associated weeds in Southeastern Brazil. Fitopatol. Bras., v. 27, n. 4, p. 372-377, 2002.

ARNAUD, L. S. E. P. et al. Predominância de begomovírus em tomateiros na região produtora da Ibiapaba, Ceará, e sua detecção em plantas daninhas. Fitopatol. Bras., v. 32, n. 3 , p. 241-246, 2007.

ASSUNÇÃO, I. P. et al. Diversidade genética de begomovírus que infectam plantas invasoras na região nordeste.

Planta Daninha, v. 24, n. 2, p. 239-244, 2006.

BRIOSO, P. S. T. et al. Identificação de espécies do gênero Comovirus através de "Polimerase Chain Reaction".

Fitopatol. Bras., v. 21, n. 2, p. 219-225, 1996.

CHAVES, A. L. R. et al. Erigeron bonariensis: Hospedeira alternativa do Lettuce mosaic virus no Brasil. Fitopatol.

Bras., v. 28, n. 3, p. 307-311, 2003

COSTA, A. S. Whitefly-transmited plant diseases. Ann. Rev. Phytopathol., v. 14, p. 429-449, 1976.

COSTA, C. L. Vetores de vírus de plantas - 1. Insetos. Rev. Anual Patol. Plantas, v. 6, p. 103-171, 1998.

DELLAPORTA, S. L.; WOOD, J.; HICKS, J. B. A plant DNA minipreparation: version II. Plant Molec. Biol. Rep., v. 1, p. 19-21, 1983.

FARIA, J. C. et al. Situação atual das geminiviroses no Brasil. Fitopatol. Bras., v. 25, n. 2, p. 125-137, 2000.

GHANIM, M. H. et al. Evidence for transovarial transmission of Tomato yellow leaf curl virus by its vector, the whitefly Bemisia tabaci. Virology., v. 240, p. 295-303, 1998 .

HAJ, F. N. P. et al. Plantas hospedeiras de Bemisia tabaci biótipo B. In: HAJ, F. N. P.; BLEICHER, E. (Eds.). Avanços no manejo da mosca-branca Bemisia tabaci biótipo B (Hemiptera: Aleyrodidae). Petrolina: Embrapa, 2004. p. 31-41. 
INOUE-NAGATA, A. K. A versatilidade do uso de técnica de RCA(amplificação por círculo rolante) na virologia. Trop.

Plant Pathol., v. 34. p. 39, 2009.

INOUE-NAGATA, A. K.; AVILA, A. C.; LOPES, C. A. Doenças viróticas. In: LOPES, C. A.; AVILA, A. C. (Eds.). Doenças do tomateiro. Brasília: Embrapa, 2005. p. 77-93.

LIMA, G. S. A. et al. Novas espécies de begomovírus associadas a plantas invasoras no Estado de Pernambuco. Fitopatol. Bras., v. 27, p. S207, 2002.

LIMA, M. F. et al. Geminivírus na cultura do tomate. In HAJ, F. N. P.; BLEICHER, E. (Eds.). Avanços no manejo da mosca-branca Bemisia tabaci biótipo B (Hemiptera: Aleyrodidae). Petrolina: Embrapa, 2004. p. 111-120.
MUNIYAPPA, V. et al. Tomato leaf curl virus from Bangalore (ToLCV-Band4); sequence comparison with Indian isolates, detection in plants and insects, and vector relationships. Arch.Virol., v. 145, p. 1583-1598, 2000

RIBEIRO, S. G. et al. Distribution and genetic diversity of tomato-infecting begomovírus in Brazil. Arch. Virol., v. 148, n. 2, p. 281-295, 2002.

RONCHI, C. P. et al. Manejo de plantas daninhas na cultura do mamoeiro. Planta Daninha, v. 26, n. 4, p. 937-947, 2008.

SANTOS, C. D. G.; GONÇALVES, M. F. B.; OLIVEIRA, O. R. Detecção, por ELISA, de begomovírus em plantas daninhas presentes em áreas produtoras de tomateiro no Estado do Ceará. Fitopatol. Bras., v. 28, p. S252, 2003. 